\title{
Effect of watershed land use on water quality: a case study in Córrego da Olaria Basin, São Paulo State, Brazil
}

\author{
M. B. L. Simedo ${ }^{a *}$, A. L. M. Martins ${ }^{b}$, T. C. T. Pissarrac, M. C. Lopes ${ }^{b}$, R. C. A. Costa ${ }^{a}$, \\ R. F. Valle-Junior ${ }^{\text {, L. C. Campanellie, N. E. T. Rojas }}{ }^{f}$ and E. L. Finoto ${ }^{b}$ \\ aprograma de Pós-Graduação em Agronomia (Ciência do Solo), Faculdade de Ciências Agrárias e Veterinárias, \\ Universidade Estadual Paulista - UNESP, Via de Acesso Prof. Paulo Donato Castellane, s/n, CEP 14884-900, Jaboticabal, \\ SP, Brazil \\ 'Polo Regional Centro Norte, Departamento de Descentralização do Desenvolvimento - APTA, Secretaria de Agricultura e \\ Abastecimento - SAA, Rodovia Washington Luis, Km 371, s/n, CEP 15830-000, Pindorama, SP, Brazil \\ 'Departamento de Engenharia Rural, Faculdade de Ciências Agrárias e Veterinárias, Universidade Estadual Paulista - \\ UNESP, Via de Acesso Prof. Paulo Donato Castellane, s/n, CEP 14884-900, Jaboticabal, SP, Brazil \\ 'Instituto Federal do Triangulo Mineiro - IFTM, Rua João Batista Ribeiro, nº 4000, Distrito Industrial II, \\ CEP 38064-790, Uberaba, MG, Brazil \\ ${ }^{\mathrm{e}}$ Campanelli Consultoria Empresarial Ltda., Avenida das Gardênias, 325 (Fundos), Cidade Jardim, \\ CEP 13566-540, São Carlos, SP, Brazil \\ ${ }^{\mathrm{f}}$ Centro de Pesquisa do Pescado Continental, Instituto de Pesca, Departamento de Descentralização do \\ Desenvolvimento - APTA, Secretaria de Agricultura e Abastecimento - SAA, Av. Abelardo Menezes, s/n, \\ CEP 15025-970, São José do Rio Preto, SP, Brazil \\ *e-mail: mariana_blopes@hotmail.com
}

Received: August 25, 2016 - Accepted: April 27, 2017 - Distributed: November 30, 2018

(With 4 figures)

\begin{abstract}
The water quality is related to the hydrologic and limnologic properties of ground and surface water, and significant efforts have been made to monitor water sources to understand the effects of land use changes in agricultural areas, with significant socioeconomic activities. The objective of this study was to evaluate the qualitative aspects of surface water in subbasins related to land use. Samples were analyzed in terms of physical and chemical parameters on monthly discrete water quality sampling in four representative sites at first order subbasin streams, located at the Polo Regional Centro Norte, Pindorama County, State of São Paulo, Brazil. The land use classification was made by visual detection technique in a multispectral satellite data obtained from LandSat8- spectral bands of the OLI sensor. The watershed was classified into major land cover/use classes and overlay maps generated in ArcGIS 10 indicated a significant shift from natural vegetation to agriculture activities. Water quality monitoring was according to the brazilian protocol and the results were submitted to analysis of variance (ANOVA). The values obtained differ significantly at each sampling point - subbasins, reflecting the effects of land use on water quality. Soil conservation management is important to optimize soil use in order to contribute to the control of water pollution and the formulation of a public policy is necessary for the conservation of water and soil resources.
\end{abstract}

Keywords: soil management, agroecosystems, land use policy.

\section{Efeito do uso do solo em sub-bacias na qualidade da água: um estudo de caso na Bacia do Córrego da Olaria, Estado de São Paulo, Brasil}

\section{Resumo}

A qualidade da água está relacionada com as propriedades hidrológicas e limnológicas das águas subterrâneas e superficiais, e esforços significativos devem ser realizados para monitorar as nascentes no intuito de compreender os efeitos das mudanças no uso da terra em áreas agrícolas, com atividades socioeconômicas significativas. O objetivo deste estudo foi avaliar os aspectos qualitativos das águas superficiais de bacias hidrográficas e correlacionar com o uso do solo. As amostras foram analisadas em termos dos parâmetros físicos e químicos na amostragem mensal discreta da qualidade da água, em quatro locais representativos de nascentes em microbacias de primeira ordem, localizadas no Polo Regional Centro Norte, Pindorama, Estado de São Paulo, Brasil. A classificação do uso do solo foi feita por técnica de detecção visual em uma imagem multiespectral de satélite LandSat8- bandas espectrais, sensor OLI. O uso do solo foi classificado nas principais classes de uso e os mapas de sobreposição gerados no ArcGIS 10 indicaram uma mudança significativa da vegetação natural para as atividades agrícolas. O monitoramento da qualidade da água 
foi realizado de acordo com o protocolo brasileiro e os resultados foram submetidos à análise de variância (ANOVA). Os valores obtidos diferem significativamente em cada ponto de amostragem, refletindo os efeitos do uso do solo sobre a qualidade da água. A gestão do solo e da água é importante para aperfeiçoar as práticas agrícolas, no intuito de contribuir para o controle da poluição da água e para a formulação de uma política pública necessária para a conservação dos recursos hídricos e do solo.

Palavras-chave: manejo do solo, agroecossistemas, política de uso do solo.

\section{Introduction}

The global development must consider the natural resources, managed and conserved based on the orientation of technological and institutional change, in such a manner as to ensure the attainment and continued satisfaction of human needs, for the present and future generations and for fighting global hunger (Food and Agriculture Organization of The United Nations, 1993; Brasil, 1988; Food and Agriculture Organization of The United Nations, 2015). The sustainability in land uses conserves soil, water, plant and animal genetic resources and is environmentally non-degrading, technically appropriate, economically viable and socially acceptable (Food and Agriculture Organization of The United Nations, 1993). To development the economic activities in agriculture is necessary to understanding the area that occurs the management of those activities (Maucieri et al., 2014; Jung et al., 2016).

The watershed is considered as a territorial unit for soil and water management (Pissarra, 2002; Tundisi, 2008; Silvino and Barbosa, 2015). Faustino et al. (2014) argue that it's an area defined topographically, drained by a watercourse and interconnected waterways systems such where the streams are discharged into a single output. It is an important unit in scientific research, training, integrated use of information for demonstration, experimentation and observation in real field, working as a natural laboratory for the short, medium and long-term studies, in order to contribute to the search for sustainable management criteria (Tundisi, 2008; Carvalho et al., 2015; Duarte-dos-Santos et al., 2016).

The management of soil use in watersheds is an indicator for assessing water and soil quality variations (Sun et al., 2016; Giri and Qiu, 2016). The study of the physical and natural aspects of the ecosystem can elucidate the direct or indirect consequences on water, mainly in an agricultural ecosystem (Moruzzi et al., 2012). Monitoring water quality provides empirical evidence to support decision making on health and environmental issues. The water quality can be assessed by physical and chemical parameters such as $\mathrm{pH}$, dissolved oxygen, temperature, electric conductivity and other parameters (Chaves and Santos, 2009; Lopes, 2011; Bateni et al., 2013; Valle Junior et al., 2014), and the values obtained from ecosystem on basis for a land use planning project and implementation of conservation practices. According to Mosca (2003), Souza and Gastaldini (2014), Giri and Qiu (2016), variations of physical and chemical parameters identify the interference of land use in water quality, expand ecological knowledge of the ecosystem and detect changes in management activities.
The monitoring of surface and groundwater can be defined a primary factor in the proper management of agroecossystems, as it allows the characterization and analysis of trends in river basins (Bortoletto et al., 2015; Giri and Qiu, 2016). The National Environmental Council - CONAMA (Brasil, 2005), through Resolution 357/2005 establishes a classification for water bodies and provides environmental guidelines for its framework (Agência Nacional de Águas, 2005). Therefore, it is extremely important to obtain values of water quality to establish indicators that can collaborate in proposals for actions and new forms of management, and conservation of soil and water in watersheds (Bortoletto et al., 2015; Sun et al., 2016; Yan et al., 2016; Ding et al., 2016).

The objective of this study was to evaluate the qualitative aspects of surface water related to land use in subbasins located in the Polo Regional Centro Norte, Pindorama County, State of São Paulo, Brazil.

\section{Material and Methods}

\subsection{Study area and data collection}

The Córrego da Olaria subbasin was located between latitudes $21^{\circ} 05^{\prime} 47^{\prime \prime} \mathrm{S}$ and $21^{\circ} 19^{\prime} 35^{\prime \prime} \mathrm{S}$ and longitudes $49^{\circ} 03^{\prime} 02^{\prime \prime} \mathrm{W}$ and $48^{\circ} 42^{\prime} 52^{\prime \prime} \mathrm{W}$ at the Polo Regional Centro Norte of the Agência Paulista de Tecnologia dos Agronegócios (APTA), Pindorama County, São Paulo State, Brazil (Instituto Brasileiro de Geografia e Estatística, 1971) - (Figure 1).

The study area was a subbasin of the São Domingos river, belonging to Turvo and Grande Rivers Watershed, that supplied water to the cities of Pindorama, Catanduva, Catiguá, Tabapuã and Uchoa, and the number of inhabitants served by the source is about 150,000 . The watershed area showed an agricultural land use with significant socioeconomic activities (Instituto de Pesquisas Tecnológicas do Estado de São Paulo, 2008; Instituto Brasileiro de Geografia e Estatística, 2016).

The climate of the watershed area is Aw according to the Climatic Classification of Köppen (1948), defined as a humid tropical climate with a rainy season in summer (Rainy) (also known as a wet season - the time of the year where the majority of a country or region's annual precipitation occurs) - from November to April; and the dry winter season (Dry) that occurred the minority precipitation - from May to October. The average temperature of the coldest month is $18^{\circ} \mathrm{C}$. The year rainfall index varied from $750 \mathrm{~mm}$ to 1,800 $\mathrm{mm}$ (Centro de Pesquisas Meteorológicas e Climáticas Aplicadas à Agricultura, 2016). 


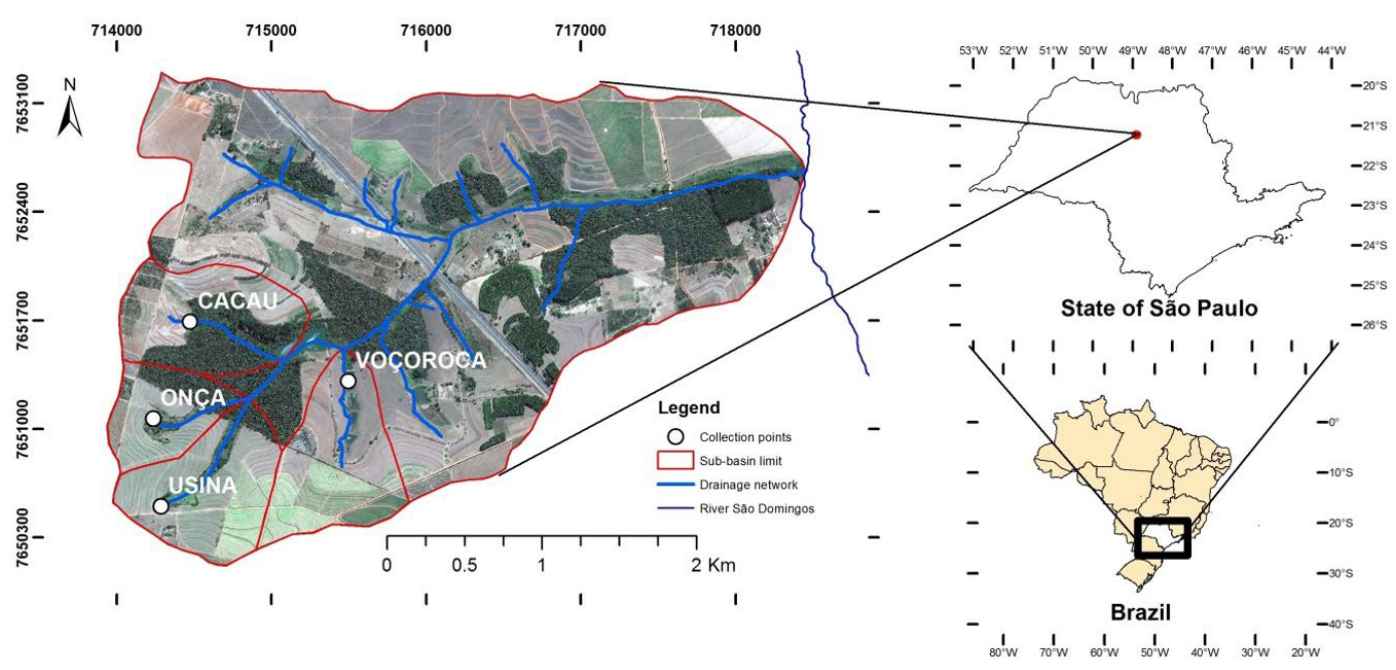

Figure 1. Study area location - Córrego da Olaria subbasin, São Paulo State, Brazil.

According to the São Paulo State Pedological Map of Oliveira et al. (1999), the soils were classified as Ultisol, Red-Yellow - PVA1: Eutrophic Abrupt A moderate, sandy/medium texture, undulating and soft undulating relief, and PVA 2: Eutrophic or non-abrupt, A moderate, sandy/medium texture and medium texture, undulating and soft undulating relief.

The water data collection was made at four main geographic subbasin regions (Cacau-C; Onça-O; Usina-U; Voçoroca-V) (Figure 1). The location of the sampling points was selected to assess the quality of the water taken and that to be representative of the water source. Each locality was considered individually and uniformly distributed at the Córrego da Olaria subbasin and the areas were of first order catchment, referred to Strahler (1957), as the Strahler stream order used to define stream size based on a hierarchy of the tributaries of the São Domingos watershed, São Paulo State, Brazil.

The water quality was monitored in the morning, for twelve months at the spring of each tributary, in the period of October 2013 to September 2014. The measurement of water quality followed the Standard Methods for Examination of Water \& Wastewater (American Public Health Association, 1999), from Brazilian Protocol. The water temperature $\left({ }^{\circ} \mathrm{C}\right)$ was measured at the site using a multiparameter measuring instrument (Horiba). Other parameters including total nitrogen $\left(\mathrm{mg} \mathrm{L}^{-1}\right)$, total phosphorus $\left(\mathrm{mg} \mathrm{L}^{-1}\right)$, hardeness $\left(\mathrm{mg} \mathrm{L}^{-1} \mathrm{CaCO}_{3}\right)$, nitrate $\left(\mathrm{mg} \mathrm{L}^{-1} \mathrm{NO}_{3}^{-}-\mathrm{N}\right)$, total ammonia $\left(\mathrm{mg} \mathrm{L}^{-1}-\mathrm{N}\right)$, fecal coliforms $(\mathrm{NMP} / 100 \mathrm{ml})$ were collected by water samples and transported in the refrigerated state, for later be analyzed at ambient temperature in the Laboratory of the International Institute of Ecology, São Carlos County, São Paulo State, Brazil.

The data analysis was submitted to descriptive statistics, used to describe the basic features of the data and to provide simple summaries about the samples and the measures.
The Shapiro-Wilk test was applied on the significance level. The analysis of variance (ANOVA) in a 5\% of significance level and a Tukey's post hoc test were used to compare the means. The differences between averages for the water parameters were evaluated using box plots (Massart et al., 2005), with graphical representations of data demonstrating an overview and a numerical summary of water quality (Ferreira et al., 2016).

The remote sensing techniques interpretation were used to complement the field survey based on ground observation and enumeration, so the high accuracy for the categories of the current land use permitted a detailed data storage (Pissarra et al., 2013). The visual interpretation was made at the LandSat 8 - sensor OIL satellite image (United States Geological Survey, 2017).

The land uses of each subbasin are distributed differently (Figure 2, Table 1), with the predominant areas of sugarcane and native forest. At the Cacau-C subbasin, the use includes sugar cane, citrus, annual crop, eucalyptus, native forest, water reservoir and reforestation; at the Onça-O subbasin: sugar cane, native forest and wet lands vegetation; at the Usina-U subbasin: sugar cane, native forest and wetland vegetation, and at the Voçoroca-V subbasin: agroforesty, sugar cane, annual crop, native forest, water reservoir, pasture and wetland vegetation.

The morphometric parameters of each subbasin were directly calculated following the methodology describe on Pissarra et al. (2004), from the vector data extracted at the topographic map of São Domingos watershed (Instituto Brasileiro de Geografia e Estatística, 1971). The data includes area (ha), perimeter $(\mathrm{km})$, maximum lenght $(\mathrm{km})$, maximum width $(\mathrm{km})$, stream lenght $(\mathrm{km})$, high altitude $(\mathrm{m})$, low altitude (m) and slope (\%). The slope was obtained in the digital elevation model -DEM at ArcGis software. For each cell, the Slope tool calculates the maximum rate of change in value from that cell to its neighbors. The tool 


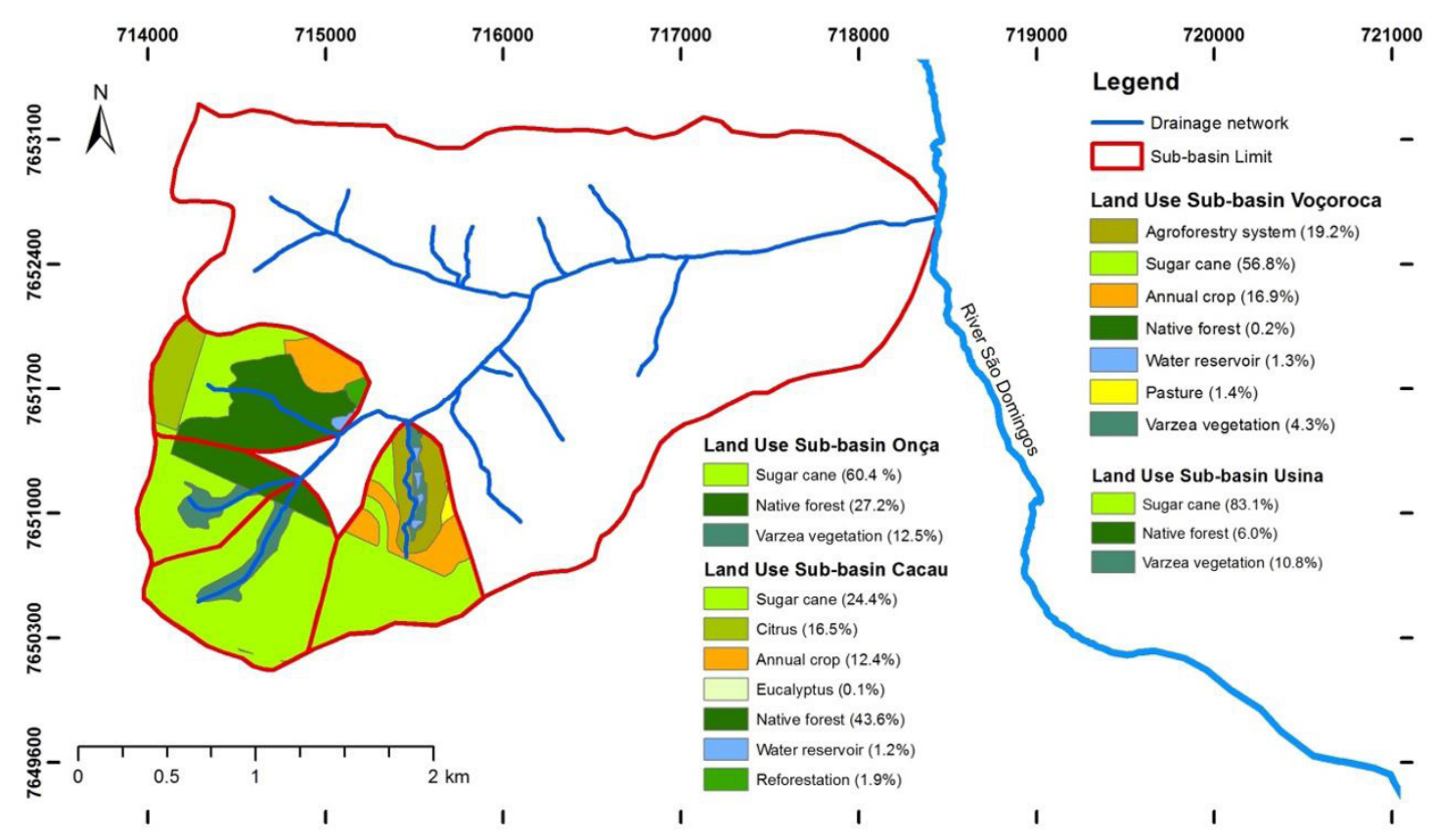

Figure 2. Land use of each subbasin at the Córrego da Olaria Basin, Pindorama, São Paulo State.

Table 1. Percentage of land use of the subbasins at the Córrego da Olaria Basin.

\begin{tabular}{|c|c|c|c|}
\hline Subbasin & Land use & Area $(\mathbf{k m})$ & Percent (\%) \\
\hline \multirow[t]{7}{*}{ Cacau (C) } & Sugar cane & 0.173 & 24.4 \\
\hline & Citrus & 0.117 & 16.5 \\
\hline & Annual crop & 0.088 & 12.4 \\
\hline & Eucalyptus & 0.001 & 0.1 \\
\hline & Native forest & 0.309 & 43.6 \\
\hline & Water reservoir & 0.008 & 1.2 \\
\hline & Reforestation & 0.014 & 1.9 \\
\hline \multirow[t]{7}{*}{ Voçoroca (V) } & Agroforesty & 0.135 & 19.2 \\
\hline & Sugar cane & 0.400 & 56.8 \\
\hline & Annual crop & 0.119 & 16.9 \\
\hline & Native forest & 0.001 & 0.2 \\
\hline & Water reservoir & 0.009 & 1.3 \\
\hline & Pasture & 0.010 & 1.4 \\
\hline & Varzea vegetation & 0.030 & 4.3 \\
\hline \multirow[t]{3}{*}{ Onça (O) } & Sugar cane & 0.241 & 60.4 \\
\hline & Native forest & 0.108 & 27.2 \\
\hline & Varzea vegetation & 0.050 & 12.5 \\
\hline \multirow[t]{3}{*}{ Usina (U) } & Sugar cane & 0.568 & 83.1 \\
\hline & Native forest & 0.041 & 6.0 \\
\hline & Varzea vegetation & 0.074 & 10.8 \\
\hline
\end{tabular}

fits a plane to the z-values of a $3 \times 3$ cell neighborhood around the processing or center cell. The slope value of this plane is calculated using the average maximum technique (Burrough and McDonell, 1998).

\section{Results}

The analysis of the morphometric characteristics provided the quantitative description of the each subbasin geometry and the slope of the drainage basin (Table 2). 
Table 2. Morphometric characteristics* of the subbasins at the Córrego da Olaria Basin.

\begin{tabular}{ccccccccc}
\hline Subbasin & $\begin{array}{c}\text { Area } \\
(\mathbf{h a})\end{array}$ & $\begin{array}{c}\text { Perimeter } \\
\mathbf{( k m )}\end{array}$ & $\begin{array}{c}\mathbf{L} \\
\mathbf{( k m )}\end{array}$ & $\begin{array}{c}\mathbf{W} \\
\mathbf{( k m )}\end{array}$ & $\begin{array}{c}\text { SI } \\
\mathbf{( k m )}\end{array}$ & $\begin{array}{c}\text { Ha } \\
(\mathbf{m})\end{array}$ & $\begin{array}{c}\text { La } \\
(\mathbf{m})\end{array}$ & $\begin{array}{c}\text { S } \\
(\mathbf{\%})\end{array}$ \\
\hline Cacau (C) & 70.88 & 3.33 & 1.11 & 0.76 & 0.82 & 601 & 555 & 6.36 \\
Onça (O) & 39.56 & 2.65 & 0.94 & 0.70 & 0.69 & 612 & 570 & 7.81 \\
Usina (U) & 68.08 & 3.31 & 1.08 & 0.93 & 0.95 & 615 & 570 & 6.99 \\
Voçoroca (V) & 71.78 & 3.63 & 1.21 & 0.89 & 0.84 & 604 & 545 & 5.65 \\
\hline
\end{tabular}

*L = maximum lenght; $\mathrm{W}=$ maximum width; $\mathrm{Sl}=$ stream lenght; $\mathrm{Ha}=$ high altitude; $\mathrm{La}=$ low altitude; $\mathrm{S}=$ slope.

The data obtained from the dimensional morphometric characteristics of each subbasin (Table 2) showed that the subbasin (V) has the largest area, followed by (C), $(\mathrm{U})$ and $(\mathrm{O})$. The highest perimeter values were found in the subbasin $(\mathrm{V})$, followed by $(\mathrm{C}),(\mathrm{U})$ and $(\mathrm{O})$, with the same sequence for the maximum length. The maximum width was identified in the subbasin (U), followed by the subbasin (V), (C) and (O). The highest value for stream length (spring drainage net) was for the subbasin (U), followed by $(\mathrm{V}),(\mathrm{C})$ and $(\mathrm{O})$.

The higher altitude was observed at the subbasin (U), followed by $(\mathrm{O}),(\mathrm{V})$ and $(\mathrm{C})$, and the altimetric amplitude was 46 meters for $(\mathrm{C}) ; 42$ meters to $(\mathrm{O}), 45$ meters to $(\mathrm{U})$ and 59 meters to $(\mathrm{V})$. The subbasin with the highest slope (7.81\%) was (O), followed by (U), (C) and (V). According to Oliveira et al. (1999), the subbasins in the Córrego da Olaria Basin presented relief soft undulating in their slope classes. There is no stepped slopes, and the average slope of the subbasins varied from $5.65 \%$ to $7.81 \%$.

The percentage of land use for each subbasin can be observed at Table 1 and Figure 2.

Land use metrics varied from areas of sugarcane $(60.4 \%)$ to native forest $(27.2 \%)$, which are the predominant areas. The land conversion and the associated impacts throughout the watershed is discussed and to characterize the rate of each land use, and the measure of the extent and percent of each use can be seen on Table 1 and Figure 2.

The surface water quality distribution among the subbasin showed significant differences (Table 3; Figures 3 and 4).

These parameters included total nitrogen $\left(\mathrm{mg} \mathrm{L}^{-1}\right)$, total phosphorus $\left(\mathrm{mg} \mathrm{L}^{-1}\right)$, nitrate $\left(\mathrm{mg} \mathrm{L}^{-1} \mathrm{NO}_{3}--\mathrm{N}\right)$, fecal coliforms ( $\mathrm{NMP} / 100 \mathrm{ml})$, hardness $\left(\mathrm{mg} \mathrm{L}^{-1} \mathrm{CaCO}_{3}\right)$, ammonium $\left(\mathrm{mg} \mathrm{L}^{-1}-\mathrm{N}\right)$ and temperature $\left(\mathrm{T}^{\circ} \mathrm{C}\right)$, shown on Figures 3 and 4.

To better understanding the natural condition of the water flowing in the subbasins streams, the total nitrogen (mg L$)^{-1}$ ) ranged from 0.30 to $1.30 \mathrm{mg} \mathrm{L}^{-1}$ in Cacau; 0.10 to $1.72 \mathrm{mg} \mathrm{L}^{-1}$ in Onça; 0.30 to $1.72 \mathrm{mg} \mathrm{L}^{-1}$ in Usina and 0.20 to $1.72 \mathrm{mg} \mathrm{L}^{-1}$ in Voçoroca (Table 3; Figure 3a). The mean concentration was $0.63-0.69 \mathrm{mg} \mathrm{L}^{-1}$. During the assessed period, the total phosphorus concentration increased slightly from 0.01 to $0.04 \mathrm{mg} \mathrm{L}^{-1}$ in all subbasins (Figure 3b).

The hardness parameter $\left(\mathrm{mg} \mathrm{L}^{-1} \mathrm{CaCO}_{3}\right)$ were highest at the Onça subbasin, ranging from 54.92 to $72.03 \mathrm{mg} \mathrm{L}^{-1} \mathrm{CaCO}_{3}$ (Figure 4a). Nitrate $\left(\mathrm{mg} \mathrm{L}^{-1} \mathrm{NO}_{3}^{--\mathrm{N}}\right)$, presented the highest value in Cacau subbasin, ranging from 2.70 to $12.29 \mathrm{mg} \mathrm{L}^{-1} \mathrm{NO}_{3}^{-}-\mathrm{N}$, (Table 3; Figure 3c). The total ammonia $\left(\mathrm{mg} \mathrm{L}^{-1}-\mathrm{N}\right)$ presented higher value and greater variability at the Voçoroca subbasin, increasing from 0 to $0.124 \mathrm{mg} \mathrm{L}^{-1}-\mathrm{N}$ and higher median value at the Usina subbasin, increasing from 0 to $0.037 \mathrm{mg} \mathrm{L}^{-1}-\mathrm{N}$ (Figure 4b). The fecal coliforms (NMP/100ml) showed the highest values at the Usina and Voçoroca subbasins (Table 3; Figure 3d). The temperature $\left(\mathrm{T}^{\circ} \mathrm{C}\right)$ was major at Voçoroca subbasin, and showed a value of $28.66{ }^{\circ} \mathrm{C}$, differing from the other subbasins that showed an average number of $22.6{ }^{\circ} \mathrm{C}$ to $18.4{ }^{\circ} \mathrm{C}$ (Table 3; Figure $4 \mathrm{c}$ ).

\section{Discussion}

The watershed is an open system and offers continuous exchange of matter and energy by the pedosphere, the atmosphere, the hydrosphere and the biosphere, which provides water percolation and the biological processes. In this study the subbasins is a structural geologic feature within Córrego da Olaria Basin that supplies water to São Domingos Watershed. This ecosystem is characterized by bodies of water such as the springs that is influenced by geochemical soil and rocks that drain as well as the interference of the climate and rainfall in their land uses (Sun et al., 2016; Yan et al., 2016). The structures of the basin ecosystems are interconnected between abiotic and biotic materials present in the environment. The integrated analysis in land uses and water monitoring in space (subbasins) and time (dry season and rainy season) allows to evaluate the possible degradation in water quality interrelated to land uses and soil management (Tundisi, 2008; Ding et al., 2016).

The water quality parameters were measured to verify the suitability of water for a particular use based on selected physical, chemical and biological characteristics. The measured and analyzed characteristics of the water such as total water temperature $\left({ }^{\circ} \mathrm{C}\right)$, total nitrogen $\left(\mathrm{mg} \mathrm{L}^{-1}\right)$, total phosphorus $\left(\mathrm{mg} \mathrm{L}^{-1}\right)$, hardeness $\left(\mathrm{mg} \mathrm{L}^{-1} \mathrm{CaCO}_{3}\right)$, nitrate $\left(\mathrm{mg} \mathrm{L}^{-1} \mathrm{NO}_{3}{ }^{-}-\mathrm{N}\right)$, ammonium $\left(\mathrm{mg} \mathrm{L}^{-1}-\mathrm{N}\right)$, fecal coliforms (NMP/100ml) (Tables 3 and 4; Figures 3 and 4) were compared to numeric standards and guidelines and to each subbasin (Figures 1 and 2), considering an ecosystem to decide if the water is suitable for a specific use.

Analyzing the water quality standards for surface water in each subbasin, the results showed that nitrogen, phosphorus, nitrate and fecal coliforms presented values higher than those recommended by the nutritional criteria used as minimum standards in Brazilian Law 


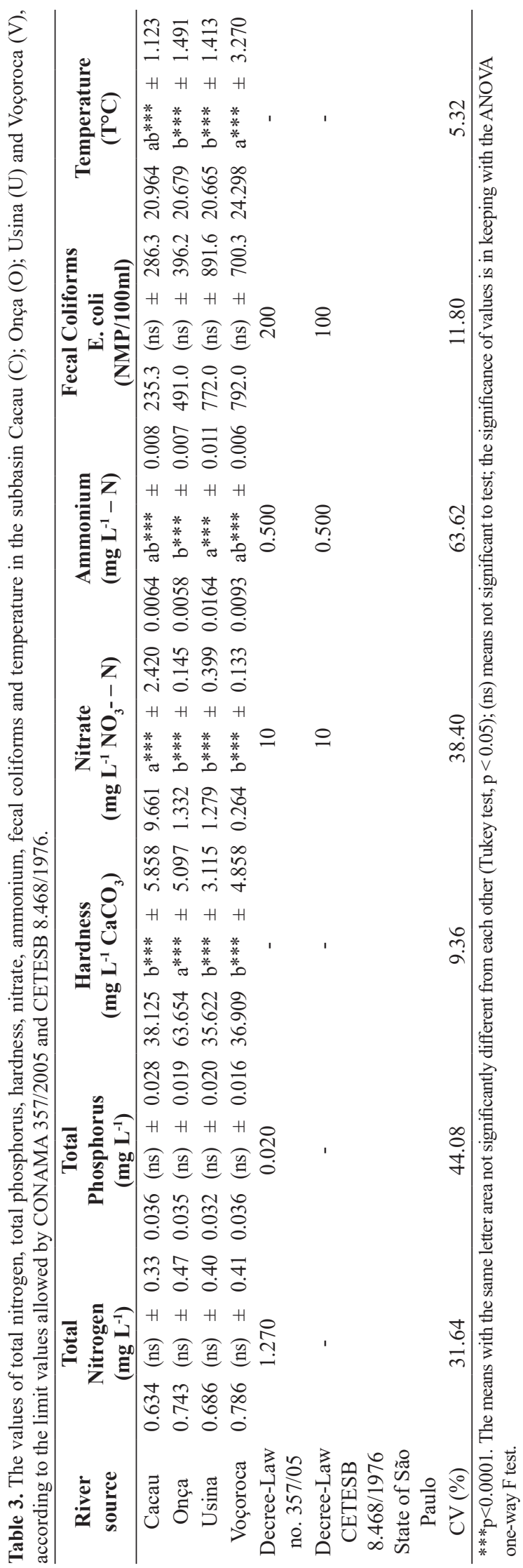



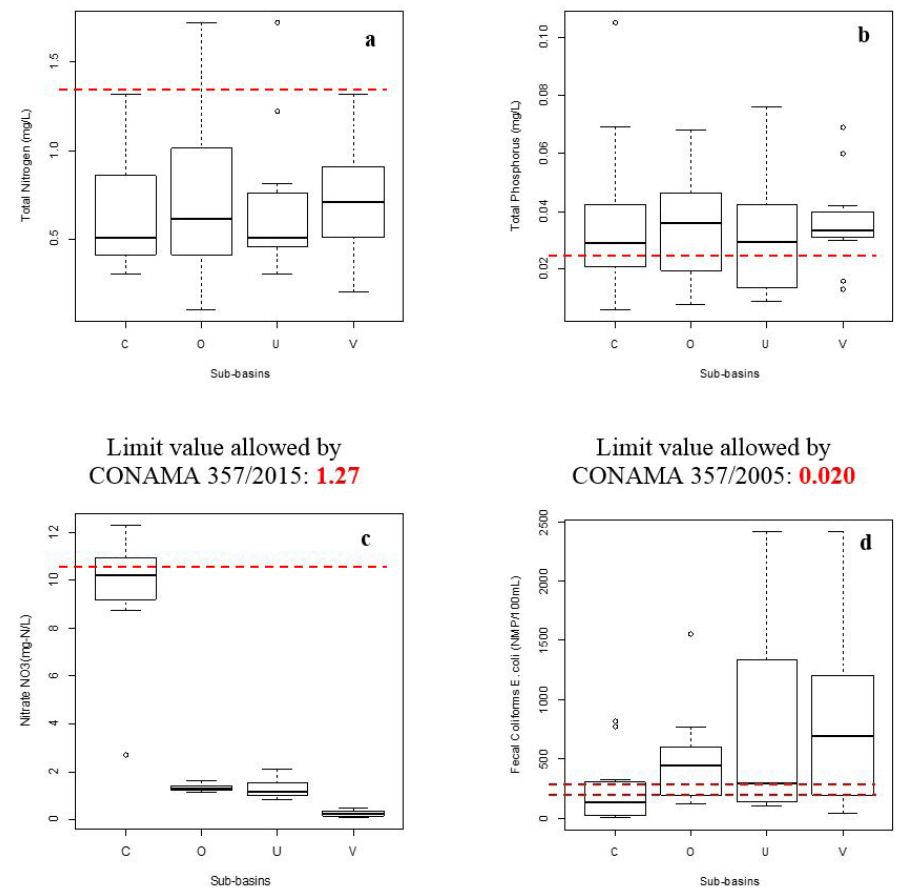

Limit value allowed by CONAMA 357/2005: 0.020

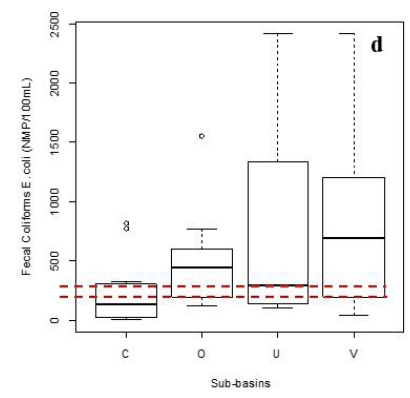

Limit value allowed by CONAMA 357/2005 Limit value allowed by CONAMA 357/2005: and CETESB 8,468/1976: 10.00 200 and CETESB 8,468/1976: 100

Figure 3. Qualitative values of total nitrogen $\left(\mathrm{mg} \mathrm{L}^{-1}\right)$, total phosphorus $\left(\mathrm{mg} \mathrm{L}^{-1}\right)$, nitrate $\left(\mathrm{mg} \mathrm{L}^{-1} \mathrm{NO}_{3^{-}}-\mathrm{N}\right)$ and fecal coliforms (NMP/100ml) at the subbasin Cacau (C); Onça (O); Usina (U) and Voçoroca (V), according to the limit values allowed by CONAMA 357/2005 and CETESB 8.468/1976.
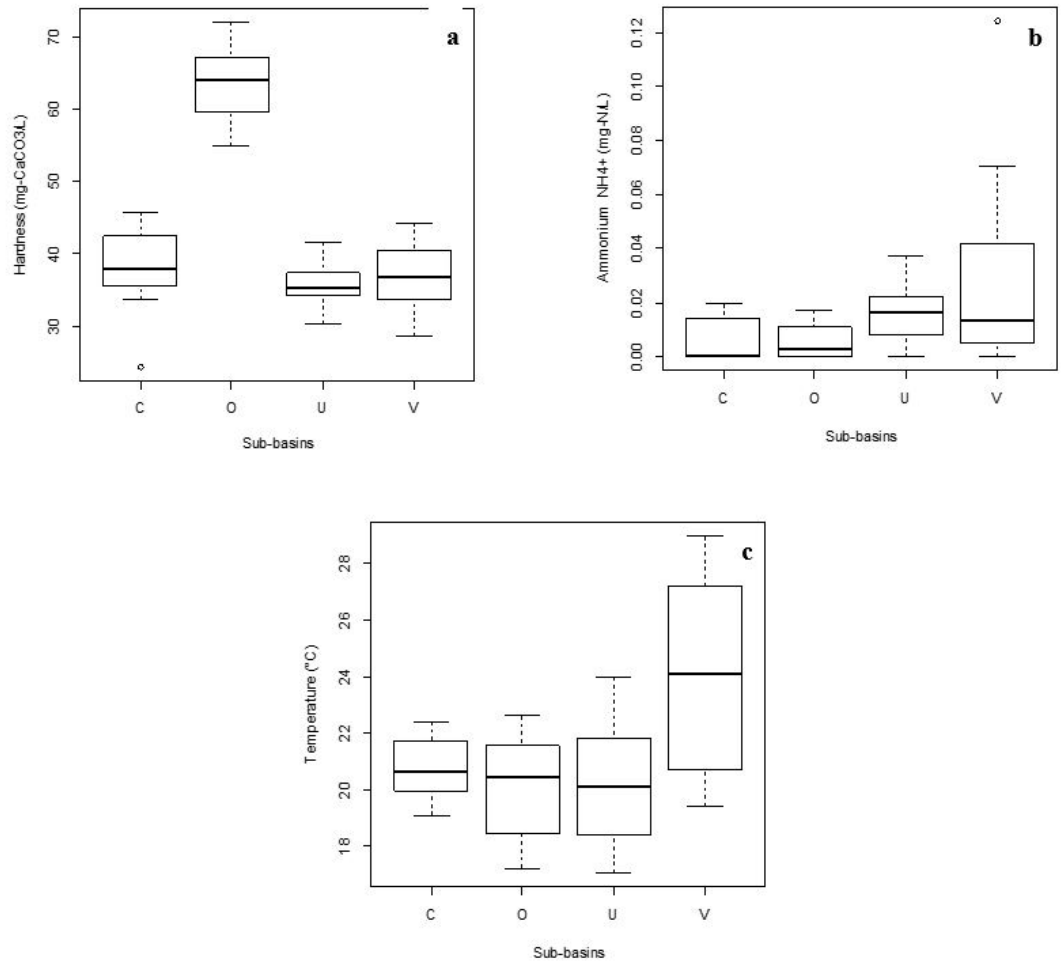

Figure 4. Qualitative values of hardness $\left(\mathrm{mg} \mathrm{L}^{-1} \mathrm{CaCO}_{3}\right)$, ammonium $\left(\mathrm{mg} \mathrm{L}^{-1}-\mathrm{N}\right)$ and temperature $\left(\mathrm{T}^{\circ} \mathrm{C}\right)$ at the $\mathrm{Cacau}(\mathrm{C})$; Onça $(\mathrm{O})$; Usina $(\mathrm{U})$ and Voçoroca $(\mathrm{V})$ subbasins. 
Table 4. Values of total nitrogen, total phosphorus, hardness, nitrate, ammonium, fecal coliforms in Rainy and Dry Seasons.

\begin{tabular}{|c|c|c|c|c|c|c|c|}
\hline Clima & Variable & Mean & & & Std. Dev. & Minimum & Maximum \\
\hline Rainy & Total Nitrogen & 0.7828 & $\mathrm{a}$ & & 0.46 & 0.10 & 1.72 \\
\hline Dry & $\mathrm{mg} \mathrm{L}^{-1}$ & 0.5713 & & b & 0.19 & 0.30 & 1.01 \\
\hline Rainy & Total Phosphorus & 0.0371 & $\mathrm{a}$ & & 0.02 & 0.01 & 0.11 \\
\hline Dry & $\mathrm{mg} \mathrm{L}^{-1}$ & 0.0340 & $\mathrm{a}$ & & 0.02 & 0.01 & 0.08 \\
\hline Rainy & Hardness & 43.8128 & $\mathrm{a}$ & & 13.60 & 24.30 & 72.03 \\
\hline Dry & & 43.1069 & $\mathrm{a}$ & & 10.88 & 34.01 & 66.82 \\
\hline Rainy & Nitrate & 2.9213 & $\mathrm{a}$ & & 3.90 & 0.10 & 11.26 \\
\hline Dry & $\mathrm{mg} \mathrm{L}^{-1}$ & 3.8231 & & $\mathrm{~b}$ & 4.32 & 0.33 & 12.29 \\
\hline & $\mathrm{NO}_{3}--\mathrm{N}$ & & & & & & \\
\hline Rainy & Amononia & 0.0094 & $\mathrm{a}$ & & 0.01 & 0.00 & 0.04 \\
\hline Dry & $m g L^{-1}-\mathrm{N}$ & 0.0134 & & $\mathrm{~b}$ & 0.01 & 0.00 & 0.03 \\
\hline Rainy & Phecal Coliform & 691.3031 & $\mathrm{a}$ & & 621.70 & 23.80 & 2419.60 \\
\hline Dry & NMP/100ml & 367.7660 & $\mathrm{a}$ & & 629.04 & 2.00 & 2419.60 \\
\hline Rainy & Temperature & 22.35 & $\mathrm{a}$ & & 2.64 & 19.00 & 28.66 \\
\hline Dry & $\mathrm{T}^{\circ} \mathrm{C}$ & 20.51 & & $\mathrm{~b}$ & 1.33 & 18.39 & 23.82 \\
\hline
\end{tabular}

(Figure 3a,b,c,d). These quantitative measurements must be constantly monitoring to comprehend the water quality of the subbasins, that are the sources of supply water to cities.

The water analysis identifies that the parameters analised is associated to impacts throughout the subbasins, characterized by the rate of crop uses, forest and wetland. The measure of the extent and rate of change in impervious surface coverage and quantifying the potential impacts of land conversion to water quality.

The results of multiple comparisons indicated that there were variations in all of the water quality parameters between the subbasins (Table 3; Figures 3 and 4). Nitrogen, in the form of nitrate, nitrite or ammonia, is a necessary nutrient for plant growth (Food and Agriculture Organization of The United Nations, 1993) and is used in agricultural practices. Nitrogen can be found in the aquatic environment, and is present with low values in water, instead of Onça that exhibited values greater than the limit stipulated by Brazilian legislation (Figure 3a). This is due to the accumulation of nutrients derived from agricultural activities. The results were also related to the high period of precipitation (Table 4), showed significant differences between dry and rainy seaons for this parameter.

The subbasins that present differet crops (Cacau) presented high values of nitrate (Table 3; Figure 3c;), due to those pesticide compounds that are already used in agriculture. The concentration of nitrate was high in agricultural areas, and this fact can be justified by the intensive use of fertilizers and pesticides in citrus and annual crops. The same process is reported in studies developed by Ding et al. (2016) and Moruzzi et al. (2012). If excess nitrate are found in the crop fields, the drained water introduces the element into the water courses (Ding et al., 2016), which will drain into other rivers and reach the São Domingos basin. Nutrients such as nitrogen, nitrate and phosphorus are essential for plant and animal growth, but the excess of certain nutrients in water can cause a number of adverse ecological and health effects (Maucieri et al., 2014).

The excess of phosphorus was shown in almost all the subbasins. The average values were higher than the limit value allowed by CONAMA (Figure $3 \mathrm{~b}$ ) and can cause the development of eutrophication of rivers and reservoirs (Tundisi, 2008). The phosphorus element in nature comes from the dissolution of the soil and the decomposition of organic matter. The parameter is present in all subbasins (Table 3; Figure 2b), with a higher value at the Cacau $0.105 \mathrm{mg} \mathrm{L}^{-1}$ and Usina $0.076 \mathrm{mg} \mathrm{L}^{-1}$. Considering that the subbasin is essentially rural and has many agricultural crops (Figure 2), this fact confirms that the land use and management activities have increased the concentration of phosphorus, which resulted in higher levels at the water sampled sites, even in dry and rainy season (Table 4).

Fecal contamination by fecal coliform parameter was identified at all sampling points (Figure 3d), with highest values in the water of Usina and Voçoroca subbasins, both with $2419.6 \mathrm{NMP} / 100 \mathrm{ml}$. The presence of fecal coliform bacteria in aquatic environments indicates that the water has been contaminated with the fecal material of man or other animals. In those areas have warm-blooded animals of the local fauna, such as an expressive population of Hydrochoerus hydrochaeris (capybaras) that come into contact with water, and at the time this occurred, the source water may have been contaminated by pathogens or disease producing bacteria or viruses which can also exist in fecal material, even in dry or rainy seasons (Table 4). The presence of Escherichia coli bacteria in food and water is an indicator of fecal contamination, that is, of human waste or of warm-blooded animals (Ponath et al., 2016). The presence of fecal contamination is an indicator that a potential health risk exists for individuals exposed to this water.

The hardness parameter does not present detection limit values established by CONAMA Resolution 357/2005 and 
CETESB 8.468/1976 (Companhia Ambiental do Estado de São Paulo, 1976), however it is important for the evaluation of the concentration of alkaline earth metals ions, especially calcium and magnesium. The Onça subbasin showed the highest hardness value of $72.03 \mathrm{mg}-\mathrm{CaCO}_{3}$ (Figure 4a), differing statistically from the others areas (Table 3 ). This water samples can be explained due to the geology of the site and nutrients from forest areas, and the dissolution of rocks and minerals. Oliveira et al. (2014) found high values of hardness in waters where there was a higher concentration of rocks containing calcium and magnesium.

The concentration of ammonium $\left(\mathrm{NH}_{4}^{+}\right)$or ammonium ion is the ionized form of Ammonia (NH3) in streams. The ammonia content may be present in surface or groundwater, usually by the decomposition of residual materials of plant or animal origin. The parameter was found at the sampling points, with highest values in water at Voçoroca and Usina subbasins (Table 3, Figure 4b) and on dry season, and those subbasins have a remarkable presence of diversified fauna of mammals and agricultural crops. Ammonium levels in the water may be related to the use of ammonia sulfate $\left(\mathrm{NH}_{4}\right)_{2} \mathrm{SO}_{4}$ in agricultural practices in the fields in the basin, in addition to the presence of urine and animal feces that approach the water bodies. Similar contaminations were identified by Delatore da Silva et al. (2014).

The temperature of the water is not a parameter in CONAMA Resolution 357/2005 and CETESB 8.468/1976, but it is considered very important because it reflects the seasonal variations of the physical-chemical parameters of the water. The highest value of temperature was observed at the Voçoroca subbasin $28.66^{\circ} \mathrm{C}$ in rainy season (Figure $4 \mathrm{c}$; Table 4), which presents an agricultural area in its surroundings and an unconsolidated reforestation, differing from other subbasins that are located in areas of native forest. The forested basins present lower water temperature levels (Arcova and Cicco, 1999). Marmontel and Rodrigues (2015) confirm that springs located in shading areas of riparian forest areas presented a lower mean temperature and lower amplitude.

The parameters used in the monitoring of the basin (total nitrogen, total phosphorus, hardness, nitrate, ammonium, fecal coliforms and temperature) indicated that the values obtained differ at each sampling point, reflecting the effects of land use on water quality. The results indicated that there was significant correlation between land uses and dry and rainy seasons to water pollution, and the subbasin that had the natural forest areas had less impacts on the water quality, while the influence of the cultivated land on the water quality was very high and remains a complex correlation, what confirm the need of more studies related to land uses changes. Besides, the impacts of the landscape diversity on the indicators of water quality within the watershed were also analyzed, the result of which indicated there was a significant positive relationship between them. The analyses of the water related to land uses changes are necessary to legislation. The National Land Use Policy is a necessary law, and the policy should cover land use and land management, and should be brought into line with international norms and standard operating procedures, in order to reflect the political changes in Watershed Management Plan. The use of land by the people must be supervised to preserve the natural resources.

\section{Conclusions}

Water quality differs at each subbasin and is linked to land uses or the conservation status of river basins.

The evaluated parameters of total nitrogen, total phosphorus, hardness, nitrate, ammonium, fecal coliforms and temperature indicated that upstream soil use is altering the water quality of the Córrego da Olaria Basin.

\section{Acknowledgements}

The authors thank the FAPESP (Fundação de Amparo à Pesquisa do Estado de São Paulo) for the financial and institutional support to carry out this project.

\section{References}

AGÊNCIA NACIONAL DE ÁGUAS - ANA, 2005 [viewed 15 February 2016]. Panorama da qualidade das águas superficiais no Brasil. Cadernos de Recursos Hídricos [online]. Brasilia: ANA. 176 p. Avaliable from: http://portalpnqa.ana.gov.br/Publicacao/ PANORAMA_DA_QUALIDADE_DAS_AGUAS.pdf

AMERICAN PUBLIC HEALTH ASSOCIATION - APHA, 1999 [viewed 25 March 2016]. Standard methods for the examination of water and wastewater [online]. 20th ed. Washington: APHA. 521 p. Avaliable from: http://www.mwa.co.th/download/file_upload/ SMWW_1000-3000.pdf

ARCOVA, F.C.S. and CICCO, V., 1999. Qualidade da água de microbacias com diferentes usos do solo na região de Cunha, Estado de São Paulo. Scientia Forestalis, vol. 5, no. 6, pp. 125-134.

BATENI, F., FAKHERAN, S. and SOFFIANIAN, A., 2013. Assessment of land cover changes \& water quality changes in the Zayadhroud river basin between 1997-2008. Environmental Monitoring and Assessment, vol. 185, no. 12, pp. 10511-10519. PMid:23892636. http://dx.doi.org/10.1007/s10661-013-3348-3.

BORTOLETTO, E.C., SILVA, H.A., BONIFÁCIO, C.M. and TAVARES, C.R., 2015. Water quality monitoring of the Pirapó River watershed, Paraná, Brazil. Brazilian Journal of Biology = Revista Brasileira de Biologia, vol. 75, no. 4, suppl. 2, pp. 148-157. PMid:26815943. http://dx.doi.org/10.1590/1519-6984.00313suppl.

BRASIL, 1988 [viewed 12 September 2016]. Constituição da República Federativa do Brasil [online]. Diário Oficial da República Federativa do Brasil, Brasília, 32 p. Available from: http://www. planalto.gov.br/ccivil_03/Constituicao/DOUconstituicao88.pdf

BRASIL. Conselho Nacional do Meio Ambiente - CONAMA, 2005 [viewed 12 November 2016]. Resolução CONAMA $n^{\circ} 357$, de 17 de março de 2005. Dispõe sobre a classifcação dos corpos de água e diretrizes ambientais para o seu enquadramento, bem como estabelece as condições e padrões de efluentes, e dá outras providencias [online]. Diário Oficial da República Federativa do Brasil, Brasília, 18 march, pp. 58-63. Available from: http://www. mma.gov.br/port/conama/res/res05/res35705.pdf 
BURROUGH, P.A. and MCDONELL, R.A. 1998. Principles of geographical information systems. 2nd ed. New York: Oxford University Press. 190 p.

CARVALHO, K.Q., LIMA, S.B., PASSIG, F.H., GUSMÃO, L.K., SOUZA, D.C., KREUTZ, C., BELINI, A.D. and ARANTES, E.J., 2015. Influence of urban area on the water quality of the Campo River basin, Paraná State. Brazilian Journal of Biology = Revista Brasileira de Biologia, vol. 75, no. 4, suppl. 2, pp. 96-106. PMid:26628235.

\section{CENTRO DE PESQUISAS METEOROLÓGICAS E CLIMÁTICAS} APLICADAS À AGRICULTURA-CEPAGRI, 2016. Clima dos municipios paulistas [online]. Campinas: CEPAGRI. Avaiable from: http://www.cepagri.unicamp.br/

CHAVES, H.M.L. and SANTOS, L.B., 2009. Ocupação do solo, fragmentação da paisagem e qualidade da água em uma pequena bacia hidrográfica. Revista Brasileira de Engenharia Agrícola e Ambiental, vol. 13, (suppl.), pp. 922-930. http://dx.doi.org/10.1590/ S1415-43662009000700015.

COMPANHIA AMBIENTAL DO ESTADO DE SÃO PAULO CETESB, 1976 [viewed 4 August 2016]. Lei estadual nº997, de 31 de maio de 1976. Dispõe sobre o controle da poluição do meio ambiente. Assembleia Legislativa do Estado de São Paulo, São Paulo, 8 september. 76 p. Available from: http://licenciamento.cetesb. sp.gov.br/legislacao/estadual/decretos/1976_Dec_Est_8468.pdf

DING, J., JIANG, Y., LIU, Q., HOU, Z., LIAO, J., FU, L. and PENG, Q., 2016. Influences of the land use pattern on water quality in low-order streams of the Dongjiang River basin, China: a multi-scale analysis. The Science of the Total Environment, vol. 551-552, pp. 205-216. PMid:26878633. http://dx.doi.org/10.1016/j. scitotenv.2016.01.162.

DUARTE-DOS-SANTOS, A.K., CUTRIM, M.V.J., FERREIRA, F.S., LUVIZOTTO-SANTOS, R., AZEVEDO-CUTRIM, A.C.G., ARAÚJO, B.O., OLIVEIRA, A.L.L., FURTADO, J.A. and DINIZ, S.C.D., 2016. Aquatic life protection index of an urban river Bacanga basin in northern Brazil, São Luís - MA. Brazilian Journal of Biology $=$ Revista Brasileira de Biologia, vol. 77, no. 3, pp. 602-615. PMid:27706393. http://dx.doi.org/10.1590/15196984.01016

FAUSTINO, A.B., RAMOS, F.F. and SILVA, S.M.P., 2014. Dinâmica temporal do uso e cobertura do solo na Bacia Hidrográfica do Rio Doce (RN) com base em sensoriamento remoto e SIG: uma contribuição aos estudos ambientais. Sociedade e Território, vol. 26, no. 2, pp. 18-30.

FERREIRA, J.E.V., PINHEIRO, M.T.S., SANTOS, W.R.S. and SILVA-MAIA, R., 2016. Graphical representation of chemical periodicity of main elements through a boxplot. Educación en la Química, vol. 27, pp. 209-216.

FOOD AND AGRICULTURE ORGANIZATION OF THE UNITED NATIONS - FAO, 1993 [viewed 10 June 2016]. The state of food and agriculture [online]. Rome: FAO. Water policies and agriculture, part III. Available from: http:/www.fao.org/ docrep/003/t0800e/t0800e00.htm

FOOD AND AGRICULTURE ORGANIZATION OF THE UNITED NATIONS - FAO, 2015 [viewed 10 June 2016]. The state of food and agriculture-social protection and agriculture: breaking the cycle of rural poverty [online]. Rome: FAO. $129 \mathrm{p}$. Available from: http://www.fao.org/publications/sofa/2015/en/

GIRI, S. and QIU, Z., 2016. Understanding the relationship of land uses and water quality in twenty first century: a review.
Journal of Environmental Management, vol. 173, pp. 41-48. PMid:26967657. http://dx.doi.org/10.1016/j.jenvman.2016.02.029.

INSTITUTO BRASILEIRO DE GEOGRAFIA E ESTATÍSTICA - IBGE, 1971 [viewed 1 January 2017]. Cartas topográficas vetoriais do mapeamento sistemático [online]. Carta do Brasil - Catanduva folha SF-22-X-D-II-1. Escala 1:50.000. Available from: http://www.ibge.gov.br/home/geociencias/download/ arquivos/index 1. shtm

INSTITUTO BRASILEIRO DE GEOGRAFIA E ESTATÍSTICA - IBGE, 2016 [viewed 5 January 2017]. Informações sobre os municipios brasileiros [online]. Available from: http://www. cidades.ibge.gov.br

INSTITUTO DE PESQUISAS TECNOLÓGICAS DO ESTADO DE SÃO PAULO - IPT, 2008 [viewed 10 July 2016]. Plano de bacia da unidade de gerenciamento de recursos hídricos da bacia do Turvo/Grande (UGRHI 15) [online]. São José do Rio Preto: IPT. 172 p. Available from: http://www.sigrh.sp.gov.br/public/ uploads/documents/7077/relatorio-final_plano-turvo_grande.pdf

JUNG, K.Y., LEE, K.L., IM, T.H., LEE, I.J., KIM, S., HAN, K.Y. and AHN, J.M., 2016. Evaluation of water quality for the Nakdong River watershed using multivariate analysis. Environmenatl Technology \& Innovation, vol. 5, pp. 67-82. http:// dx.doi.org/10.1016/j.eti.2015.12.001.

KÖPPEN, W. 1948. Climatologia: conunestudio de los climas de latierra. México: Fondo de Cultura Econômica, 479 p.

LOPES, M.C. 2011. Ações de educação ambiental e monitoramento da água no córrego da Olaria, Apta-Pindorama, SP. Jaboticabal: Faculdade de Ciências Agrárias e Veterinárias, Universidade Estadual Paulista, 64 p. Dissertação de Mestrado em Agronomia, Programa de Pós-Graduação em Ciência do Solo.

MARMONTEL, C.V.F. and RODRIGUES, V.A., 2015. Parâmetros indicativos para qualidade da água em nascentes com diferentes coberturas de terra e conservação da vegetação ciliar. Revista Floresta e Ambiente, vol. 22, no. 2, pp. 171-181. http://dx.doi. org/10.1590/2179-8087.082014.

MASSART, D.L., SMEYERS-VERBEKE, J., CAPRON, X. and SCHLESIER, K., 2005. Visual presentation of data by means of box plots. LC GC Europe, vol. 18, pp. 215-218.

MAUCIERI, C., SALVATO, M., TAMIAZZO, J. and BORIN, M., 2014. Biomass production and soil organic carbon accumulation in a free water surface constructed wetland treating agricultural wastewater in North Eastern Italy. Ecological Engineering, vol. 70, pp. 422-428. http://dx.doi.org/10.1016/j.ecoleng.2014.06.020.

MORUZZI, R.B., CONCEIÇÃO, F.T., SARDINHA, D.S., HONDA, F.P. and NAVARRO, G.R.B., 2012. Avaliação de cargas difusas e simulação de autodepuração no córrego da água branca, Itirapina (SP). Geociências, vol. 31, no. 3, pp. 447-458.

MOSCA, A.A.O. 2003. Caracterização hidrológica de duas microbacias visando a identificação de indicadores hidrológicos para o monitoramento ambiental de manejo de florestas plantadas. Piracicaba: Escola Superior de Agricultura Luis de Queiroz, Universidade de São Paulo, 96 p. Dissertação de Mestrado em Recursos Florestais.

OLIVEIRA, J.B., CAMARGO, M.N., ROSSI, M. and CALDERANO FILHO, B. 1999. Mapa pedológico do Estado de São Paulo: legenda expandida. Campinas: Instituto Agronômico, Embrapa Solos. 64 p. Escala 1:500.000.

OLIVEIRA, K.B.M., DE MORAIS, F. and BACELLAR, F.A.P., 2014. Distribuição de parâmetros hidroquímicos das águas 
subterrâneas na região da Lagoa da Confusão - TO - Brasil. Ambiência Guarapuava (PR), vol. 10, no. 1, pp. 281-302.

PISSARRA, T.C.T. 2002. Análise da bacia hidrográfica do Córrego Rico na sub-região de Jaboticabal, SP: comparação entre imagens TM-LANSAT 5 e fotografias aéreas verticais. Jaboticabal: Faculdade de Ciências Agrárias e Veterinárias, Universidade Estadual Paulista. 132 p. Tese de Doutorado em Agronomia, Programa de Pós-Graduação em Produção Vegetal.

PISSARRA, T.C.T., MARCUSSI, A.B., LEÃO, G.R., GALBIATTI, J.A., BORGES, M.J. and CAMPOS, S., 2013. Environmental adaptation of the source of the subbasin of Rico Stream, Monte Alto - SP, Brazil. Engenharia Agrícola, vol. 33, no. 2, pp. 303-311. http://dx.doi.org/10.1590/S0100-69162013000200009.

PISSARRA, T.C.T., POLITANO, W. and FERRAUDO, A.S., 2004. Avaliação de características morfométricas na relação solo-superfície da bacia hidrográfica do Córrego Rico, Jaboticabal (SP). Revista Brasileira de Ciência do Solo, vol. 28, no. 2, pp. 297-305. http://dx.doi.org/10.1590/S0100-06832004000200008.

PONATH, F.S., VALIATTI, T.B., SOBRAL, F.O.S., ROMÃO, N.F., ALVES, G.M.C. and PASSONI, G.P., 2016. Avaliação da higienização das mãos de manipuladores de alimentos do Município de Ji-Paraná, Estado de Rondônia, Brasil. Pan-Amazônica de Saúde, vol. 7, no. 1, pp. 63-69. http://dx.doi.org/10.5123/S217662232016000100008 .

SILVA, D.D., MIGLIORINI, R.B., SILVA, E.C., LIMA, Z.M. and MOURA, I.B., 2014. Falta de saneamento básico e as águas subterrâneas em aquífero freático: região do bairro Pedra Noventa, Cuiabá (MT). Engenharia Sanitaria e Ambiental, vol. 19, no. 1, pp. 43-52. http://dx.doi.org/10.1590/S1413-41522014000100005.

SILVINO, R.F. and BARBOSA, F.A.R., 2015. Eutrophication potential of lakes: an integrated analysis of trophic state, morphometry, land occupation, and land use. Brazilian Journal of Biology $=$ Revista Brasileira de Biologia, vol. 75, no. 3, pp. 607-615. http://dx.doi.org/10.1590/1519-6984.18913.

SOUZA, M.M. and GASTALDINI, M.C.C., 2014. Avaliação da qualidade da água em bacias hidrográficas com diferentes impactos antrópicos. Engenharia Sanitaria e Ambiental, vol. 19, no. 3, pp. 263-274. http://dx.doi.org/10.1590/S1413-41522014019000001097.

STRAHLER, A.N., 1957. Quantitative analysis of watershed geomorphology. Transactions - American Geophysical Union, vol. 6, no. 38, pp. 913-920. http://dx.doi.org/10.1029/TR038i006p00913.

SUN, W., XIA, C., XU, M., GUO, J. and SUN, G., 2016. Application of modified water quality indices as indicator to assess the spatial and temporal trends of water quality in the Dongjiang River. Ecological Indicators, vol. 66, pp. 306-312. http://dx.doi. org/10.1016/j.ecolind.2016.01.054.

TUNDISI, J.G., 2008. Recursos hídricos no futuro: problemas e soluções. Estudos Avançados, vol. 22, no. 63, pp. 7-16. http:// dx.doi.org/10.1590/S0103-40142008000200002.

UNITED STATES GEOLOGICAL SURVEY - USGS, 2017 [viewed 10 January 2017]. Credit: U.S. geological survey. [online]. United States: Department of the Interior. Available from: https:// www2.usgs.gov/pubprod/LandSat8

VALLE JUNIOR, R.F., VARANDAS, S.G., SANCHES FERNANDES, L.F. and PACHECO, F.A., 2014. Groundwater quality in rural watersheds with environmental land use conflicts. The Science of the Total Environment, vol. 493, pp. 812-827. PMid:25000577. http://dx.doi.org/10.1016/j.scitotenv.2014.06.068.

YAN, W., LI, J. and BAI, X., 2016. Comprehensive assessment and visualized monitoring of urban drinking water quality. Chemometrics and Intelligent Laboratory Systems, vol. 155, pp. 26-35. http://dx.doi.org/10.1016/j.chemolab.2016.03.026. 